\title{
The change in oestrogen and progesterone levels triggers adovarian propulsive movement of the hamster oviduct
}

\author{
D. E. Battalia* and R. Yanagimachi \\ Department of Anatomy and Reproductive Biology, University of Hawaii Medical School, \\ Honolulu, Hawaii 96822, U.S.A.
}

\begin{abstract}
Summary. Effects of oestrogen and progesterone on oviduct movement were observed in vivo in ovariectomized hamsters. Continuous administration of oestradiol via implanted Silastic tubing did not induce co-ordinated propulsive movement of the oviduct towards the ovary, but the withdrawal of the hormone did. The most efficient adovarian propulsion was observed when the withdrawal of oestradiol was combined with progesterone administration. Progesterone alone did not stimulate this type of movement.
\end{abstract}

\section{Introduction}

As reported previously (Battalia \& Yanagimachi, 1979), the hamster oviduct displays very coordinated adovarian propulsive movement during a $7 \mathrm{~h}$ period around the time of ovulation. This phenomenon was also observed by Blandau (1978) when he injected small boluses of mineral oil into the lumen of the oviduct isthmus of the oestrous rat. The oil was promptly transported to the ampulla by an adovarian contractile movement of the isthmus. Similar observations were made on the oviduct of the pig near the time of ovulation (Blandau \& Gaddum-Rosse, 1974). The physiological function of this type of oviduct movement is not clear, but it is possible that the movement may play a role in directing spermatozoa towards the ampulla where fertilization takes place.

The physiology (including the muscular movement) of the oviduct, like that of other parts of the female tract, is under the control of the endocrine and autonomic nervous systems (Boling, 1969; Black, 1974; Kennedy \& Marshall, 1977; Paton, Widdicombe, Rheaume \& Johns, 1977). In the hamster, the concentration of plasma oestradiol reaches its peak approximately 10-12 h before ovulation and declines to very low levels before ovulation (Baranczuk \& Greenwald, 1973). It is also during this preovulatory period that a rise and subsequent fall of plasma progesterone occurs (Lukaszewska \& Greenwald, 1969; Norman \& Greenwald, 1971). Oviduct muscle, while quiescent under oestrogen influence, vigorously contracts when the hormone is withdrawn (Boling, 1969; Boling \& Blandau, 1971). The present experiments were designed to confirm that the adovarian propulsive movement of the hamster oviduct during the preovulatory period is provoked by changes in peripheral oestrogen and progesterone concentrations.

* Present address: Oregon Primate Research Center, Beaverton, Oregon 97005, U.S.A. 


\section{Materials and Methods}

Sexually mature, virgin golden hamster females weighing 100-140 g were used. One group of females was unilaterally ovariectomized, care being taken not to injure any part of the oviduct. The surgery was accomplished using methyoxyflurane vapour and microsurgical techniques. It did not interrupt the normal oestrous cycle of the females. These females received no hormone treatments and their oviducts were observed 1-2 weeks after ovariectomy. The remaining females were bilaterally ovariectomized. Again, great care was taken not to damage the oviducts. After recovery for 1-2 weeks, the bilaterally ovariectomized animals were allocated to 4 groups. Females in Group I received no further treatment and were used as controls. Group II females received a subcutaneous injection of $2 \mathrm{mg}$ progesterone (Sigma Chemical Co., St Louis, Missouri) in $0.2 \mathrm{ml}$ sesame oil $3 \mathrm{~h}$ before examination of their oviducts. Females in Group III received a subcutaneous implant consisting of a $5 \mathrm{~mm}$ length of Silastic tubing (Dow Corning Corp., Midland, Michigan) packed with crystalline oestradiol benzoate (Nutritional Biochemicals Corp., Cleveland, Ohio) (Kincl, Benagiano \& Angee, 1968). The implant was removed after 3 days and the oviducts were examined $0-12 \mathrm{~h}$ later. The animals in Group IV were treated like those in Group III except that they received a subcutaneous injection of $2 \mathrm{mg}$ progesterone $9 \mathrm{~h}$ after removal of the implants. Their oviducts were examined $3 \mathrm{~h}$ after the progesterone injection.

The adovarian propulsive movement of the oviduct was monitored as described by Battalia \& Yanagimachi (1979) by (1) observing the behaviour of a small amount of India ink injected into the lowermost segment of the extramural isthmus and (2) determining the time needed for transport of the ink to the ampulla.

\section{Results}

Table 1 summarizes the results obtained from the unilaterally ovariectomized females during ovulation. Ink injected into the isthmus of the oviduct on the operated side was transported to the ampulla at the same rate as ink injected into the intact side.

Table 1. Mean time \pm s.e.m. required for ink to reach the ampullary region of the oviduct of unilaterally ovariectomized hamsters*

\begin{tabular}{lccc}
\hline & & \multicolumn{2}{c}{$\begin{array}{c}\text { Time }(\mathrm{sec}) \text { required for } \\
\text { ink to reach: }\end{array}$} \\
\cline { 3 - 4 } \multicolumn{1}{c}{ Oviduct } & $\begin{array}{c}\text { No. of } \\
\text { animals }\end{array}$ & $\begin{array}{c}\text { Lower } \\
\text { ampulla }\end{array}$ & $\begin{array}{c}\text { Upper } \\
\text { ampulla }\end{array}$ \\
\hline $\begin{array}{l}\text { Intact side } \\
\begin{array}{l}\text { Ovariectomized } \\
\text { side }\end{array}\end{array}$ & 5 & $25.0 \pm 4.0$ & $68.1 \pm 11.8$ \\
\hline
\end{tabular}

* Observations were made during ovulation, i.e. 01:00 to 03:00 h on Day 1 of the oestrous cycle.

The results from Groups I-IV are presented in Table 2. The oviducts of Group I females were quiescent and considerably smaller than those of intact animals. Most of the injected ink was expelled through the injection hole within 3-4 sec and none progressed beyond the isthmus. Oviducts of females in Group II behaved similarly to those in Group I in that the injected ink was not propelled towards the ampulla. However, the ink was expelled into the uterus through the utero-tubal junction within 5-100 sec. 
Table 2. Mean time \pm s.e.m. required for ink to reach the ampullary segment of the oviduct after various hormone treatments of bilaterally ovariectomized hamsters

\begin{tabular}{|c|c|c|c|c|c|c|}
\hline \multirow[b]{2}{*}{ Group } & \multirow[b]{2}{*}{ Treatment } & \multirow{2}{*}{$\begin{array}{l}\text { Time of ink } \\
\text { injection into } \\
\text { the isthmus }\end{array}$} & \multirow[b]{2}{*}{$\begin{array}{l}\text { No. of } \\
\text { animals }\end{array}$} & \multicolumn{2}{|c|}{$\begin{array}{l}\text { Time }(\mathrm{sec}) \text { required for } \\
\text { ink to reach: }\end{array}$} & \multirow{2}{*}{$\begin{array}{l}\text { No. of animals } \\
\text { in which ink was } \\
\text { transported to } \\
\text { the upper ampulla }\end{array}$} \\
\hline & & & & $\begin{array}{l}\text { Lower } \\
\text { ampulla }\end{array}$ & $\begin{array}{l}\text { Upper } \\
\text { ampulla }\end{array}$ & \\
\hline I & None & - & 4 & - & - & 0 \\
\hline II & $\begin{array}{l}\text { Progesterone, } \\
\text { s.c. }\end{array}$ & $\begin{array}{l}3 \mathrm{~h} \text { after } \\
\text { progesterone } \\
\text { injection }\end{array}$ & 4 & - & - & 0 \\
\hline \multirow[t]{3}{*}{ III } & $\begin{array}{r}\text { Oestradiol } \\
\text { implant }\end{array}$ & $\begin{array}{l}\text { (a) } 0-6 \mathrm{~h} \text { after } \\
\text { implant removal }\end{array}$ & 4 & $180^{*}$ & - & 0 \\
\hline & & $\begin{array}{l}\text { (b) } 7-8 \mathrm{~h} \text { after } \\
\text { implant removal }\end{array}$ & 4 & $31 \cdot 3 \pm 5 \cdot 2$ & $40 \cdot 0^{*}$ & 1 \\
\hline & & $\begin{array}{l}\text { (c) 9-12 h after } \\
\text { implant removal }\end{array}$ & 7 & $34 \cdot 4 \pm 6 \cdot 1$ & $170 \cdot 8 \pm 64 \cdot 0$ & 7 \\
\hline IV & $\begin{array}{l}\text { Oestradiol } \\
\text { implant } \\
\text { followed by } \\
\text { progesterone, } \\
\text { s.c. }\end{array}$ & $\begin{array}{l}3 \mathrm{~h} \text { after } \\
\text { progesterone ( } 12 \mathrm{~h} \\
\text { after implant } \\
\text { removal) }\end{array}$ & 5 & $57.5 \pm 12.0$ & $151.7 \pm 7.5$ & 5 \\
\hline
\end{tabular}

* Only one animal exhibited ink transport to this region.

Various degrees of adovarian propulsive movement were observed in Group III females. In Group IIIa, the ink spread throughout the length of the isthmus by a to-and-fro jostling movement of the isthmus, but did not usually advance beyond the ampullary-isthmic junction and was eventually expelled into the uterus. In Group IIIb, ink reached the lower ampulla in all females, but did not usually progress to the upper ampulla. In Group IIIc ink was transported to the upper ampulla in all the females. To-and-fro jostling movements of the isthmus and ampulla tended to spread the ink throughout the length of the entire oviduct within $10 \mathrm{~min}$, and no more than $50 \%$ of the total ink injected into the isthmus reached the ampulla. No ink was expelled into the uterus during the observation period in Group IIIb or IIIc females.

Group IV females demonstrated the most efficient adovarian transport of ink. After injection, the ink rapidly accumulated next to the ampullary-isthmic junction and was released as small boluses into the ampulla every few seconds. Eventually $90-100 \%$ of the injected ink was propelled into the upper ampulla.

\section{Discussion}

The oviducts of ovariectomized females are quiescent in both the rabbit (Greenwald, 1963) and the hamster. Administration of oestrogen to spayed animals restores the ability of the oviduct to contract (Greenwald, 1963). The involvement of progesterone secreted before ovulation in increasing the muscular contractility of the rabbit oviduct has been suggested by Boling \& Blandau (1971). The present study has demonstrated that a co-ordinated adovarian propulsion of the hamster oviduct, which rapidly propels injected ink to the upper ampulla (Battalia \& Yanagimachi, 1979), is provoked in ovariectomized females when oestrogen treatment is withdrawn. Administration of progesterone in combination with oestrogen withdrawal increased the efficiency of the adovarian ink transport. Nearly $100 \%$ of the injected ink reached the ampulla in these animals, whereas less than $50 \%$ of the ink reached the ampulla in oestrogentreated females. 
The results obtained from the progesterone-treated females follow those of previous studies demonstrating that progesterone decreases smooth muscle activity in the oviducts of women (Coutinho, Maia \& Mattos, 1975) and rabbits (Salomy \& Harper, 1971). Martin, Ware, Crosby \& Pauerstein (1970) suggested that progesterone exerts its influence on oviduct motility by enhancing beta-adrenoceptor activity in the oviduct. Other investigators have suggested that progesterone may exert its influence by altering calcium movements and binding (Higgs \& Moawad, 1974; Hodgson \& Daly, 1976).

The rapid, but transient appearance of adovarian propulsion after oestrogen pretreatment in the hamster suggests that it may be partly controlled by the autonomic nervous system. The mammalian oviduct contains varied densities of adrenoceptors and their influence depends upon the levels of oestrogen and progesterone in many animals (Black, 1974; Paton et al., 1977). Alpha-adrenergic blocking agents like phenoxybenzamine and phentolamine have inhibited the normal contractile response to nerve stimulation in human Fallopian tubes (Nakanishi \& Wood, 1968) and rabbit oviducts (Ueda, Mattos \& Coutinho, 1973), implicating the involvement of alpha-adrenoceptors in control of oviduct motility. This idea is further supported by the observed oestrogen-induced increase in the innervation density and norepinephrine content in the rabbit oviduct (Kennedy \& Marshall, 1977). The norepinephrine content also increases in the isthmus of the human oviduct during the follicular phase of the menstrual cycle, suggesting that an increase in adrenergic reception is concomitant with alterations in smooth muscle activity and ovum transport (Paton et al., 1977). It is therefore possible that the alterations in smooth muscle activity resulting in adovarian propulsion in the hamster are also mediated through alterations in adrenergic activity due to hormone changes.

In intact, ovulating animals the ampullary-isthmic junction did not impede the transport of ink from the upper isthmus to the ampulla. However, in females of Group IV the injected ink tended to accumulate near the ampullary-isthmic junction before being transported to the ampulla, perhaps because this region, which contains the greatest concentration of autonomic nerve endings of any segment of the oviduct (Black, 1974), was overstimulated by supraphysiological oestrogen concentrations. The Silastic implants that we used released oestradiol at a rate of approximately $5 \mu \mathrm{g} /$ day (Kincl et al., 1968) and oestrogen has been shown to potentiate effects mediated by adrenoceptors (Howe \& Black, 1973; Paton et al., 1977). Hence, stimulation of the high concentration of receptors in the ampullary-isthmic junction may have resulted in periodic constriction of this region, thus preventing continuous transport of ink to the ampulla. To restore normal adovarian propulsive movement of the oviduct in ovariectomized animals, the levels of hormones and the timing of their administration may need to be controlled more carefully.

This work was supported by a grant from the U.S. Public Health Service (HD-03402). We thank Professor R. J. Blandau for advice and Mrs Cherrie Mahi-Brown, Mrs Michele Ikeda and Ms Beth Jeppesen for their assistance in the preparation of the manuscript.

\section{References}

Baranczuk, R. \& Greenwald, G.S. (1973) Peripheral levels of estrogen in the cyclic hamster. Endocrinology 92, 805-812.

Battalia, D.E. \& Yanagimachi, R. (1979) Enhanced and co-ordinated movement of the hamster oviduct during the periovulatory period. J. Reprod. Fert. 56, 515-520.

Black, D.L. (1974) Neural control of oviduct musculature. In The Oviduct and Its Functions, pp. 65118. Eds A. D. Johnson \& C. W. Foley. Academic Press, New York.
Blandau, R.J. (1978) Gamete transport in oviducts of rats. Anat. Rec. 190, 593, Abstract.

Blandau, RJ. \& Gaddum-Rosse, P. (1974) Mechanism of sperm transport in the pig oviduct. Fert. Steril. 25, $61-67$.

Boling J.L. (1969) Endocrinology of oviduct musculature. In The Mammalian Oviduct, pp. 163-191. Eds E. S. E. Hafez \& R. J. Blandau. University of Chicago Press, Chicago.

Boling, J.L. \& Blandau, R.J. (1971) Egg transport through the ampullae of the oviducts of rabbits under 
various experimental conditions. Biol. Reprod. 4, 174-184.

Coutinho, E.M., Maia, H. \& Mattos, C.E.R. (1975) Contractility of the fallopian tube. Gynecol. Invest. 6, 146-161.

Greenwald, G.S. (1963) In vivo recording of intraluminal pressure changes in the rabbit oviduct. Fert. Steril. 14, 666-674.

Higgs, G.W. \& Moawad, A.H. (1974) The effect of ovarian hormones on the contractility of the rabbit isthmus. Can. J. Physiol. Pharmac. 52, 78-83.

Hodgson, B.J. \& Daly, S. (1976) The role of calcium in contraction of the oviduct. In Ovum Transport and Fertility Regulation, pp. 182-196. Eds M. J. K. Harper, C. J. Pauerstein, C. E. Adams, E. M. Coutinho, H. B. Croxatto \& D. M. Paton. Scriptor, Copenhagen.

Howe, I. \& Black, D.L. (1973) Autonomic nervous system and oviduct function in the rabbit. J. Reprod. Fert. 33, 425-430.

Kennedy, D.R. \& Marshall, J.M. (1977) Effect of adrenergic nerve stimulation on the rabbit oviduct: correlation with norepinephrine content and turnover rate. Biol. Reprod. 16, 200-211.

Kincl, F.A., Benagiano, G. \& Angee, I. (1968) Sustained release hormonal preparations. I. Diffusion of various steroids through polymer membranes. Steroids 11, 673-691.
Lukaszewska, J.H. \& Greenwald, G.S. (1969) Progesterone levels in the cyclic and pregnant hamster. Endocrinology 86, 1-9.

Martin, J.E., Ware, R.W., Crosby, R.J. \& Pauerstein, C.J. (1970) Demonstration of beta adrenergic receptors in the rabbit oviduct. Gynecol. Invest. 1, 82-91.

Nakanishi, H. \& Wood, C. (1968) Effects of adrenergic blocking agents on human fallopian tube motility in vitro. J. Reprod. Fert. 16, 21-28.

Norman, R.L. Greenwald, G.S. (1971) Effect of phenobarbitol, hypophysectomy and $\mathrm{X}$-irradiation on preovulatory progesterone levels in the cyclic hamster. Endocrinology 89, 598-605.

Paton, D.M., Widdicombe, J.H., Rheaume, D.E. \& Johns, A. (1977) The role of adrenergic innervation of the oviduct in regulation of mammalian ovum transport. Pharm. Rev. 29, 67-102.

Salomy, M. \& Harper, M.J.K. (1971) Cyclical changes of oviduct motility in rabbits. Biol. Reprod. 4, 185194.

Ueda, M., Mattos, C.E.R. \& Coutinho, E.M. (1973) The influence of adrenergic activation and blockade on motility of the circular and longitudinal muscle layers of the rabbit oviduct in vitro. Fert. Steril. 24, 440443.

Received 3 December 1979 